\title{
Adopting Geo-ICT in Survey Department: Need for Capacity Building
}

\author{
Kalyan Gopal Shrestha \\ Chief Survey Officer, Survey Department \\ e-mail:kalyanshrestha@gmail.com
}

\begin{abstract}
The Geospatial Information and Communication Technology (Geo-ICT), is gaining momentum and has revolutionized the Surveying and Mapping profession. Since the geo-technology is evolving continuously, constant efforts are being made for its diverse applications. Most of the users are convinced that digital technology is known for its easy use and the power to improve their work process. Survey Department has witnessed tremendous changes in the technologies and corresponding policies in Global scenario in last fifty two years of its history and particularly during last two decades. Adoption of GeoICT has become indispensable in the present context. Even though Survey Department, so far, is not in the stage of fully exploiting the Geo-ICT, Time has come to think of adopting Geo-ICT application. Because, the wider use of Geo-ICT could be prime instrumental to support the overall Surveying and Mapping business. The success of efficient Geo-ICT application heavily depends on the capacity building, institutional reforms, devolution, education and continuous training, and ultimately the commitment of the government.
\end{abstract}

This article has tried to focus on various factors responsible for successful implementation of Geo-ICT in Nepalese context.

\section{Introduction of Geo-ICT}

Geo-ICT means Geospatial Information and Communication Technology. The concept of Geo-ICT is to integrate the Geospatial technology into the mainstream of Information and Communication Technology. Geo-ICT is rapidly gaining momentum as key research methodology in geography, environmental science etc.

Geo-Information and Communication Technology (Geo-ICT) includes convergence of various modern technologies dealing with various aspects of spatial data management including: data acquisition, data integration, data analysis, information generation, decision support, and information dissemination. Geographic Information System (GIS), Remote Sensing (RS), Global Positioning System (GPS), satellite communication system and web technologies are the chief technologies falling under GeoICT.

There are many Geo-ICT applications. GIS could be considered as part of Geo-ICT. Geo-ICT provides even broader applications that traditional GIS may have not addressed well. Geo-ICT is truly an interdisciplinary area that would require the integration of GIS, GPS (position tracking), RS (remote sensing), satellite wireless communication systems, mapping technologies etc..

Geo-spatial revolution led to acquire and update knowledge towards high end research resulting Geo-ICT. The role of Geo-ICT has become vital for local level geospatial planning. Spatial data management includes: data acquisition, data assimilation, data analysis, information extraction, decisions support and data/ information dissemination.

\section{Necessity for adopting Geo-ICT}

Now-a-days, most of the professionals have moved from conventional analogue to digital. Since the geo-technology is evolving continuously, constant efforts are made in its diverse applications. This acceptance comes from a growing understanding about the technology and its benefits. Most of the users are convinced that digital technology is known for its easy use and the power to improve their work process.

The twenty-first century is the age of ICT and numbers of technologies are evolving day by day to accelerate the efforts for the maximum yields. Among the many applications of the information technology, Spatial Information System holds the potentiality of rendering significant contribution on policy-making, formulation of plans, infrastructure development, natural 
resource management and other development activities. The blending of ICT applications with Geomatics (GEO-ICT) is providing new insights into global issues such as the patterns and degradation of forests, climatic change, home land security and prevention of cultural heritages, monitoring of crops, war strategies and conflict management activities.

Even though the traditional disciplines were very essential for infrastructure development of mapping, the specialized and modern areas are becoming more important for comfort, safety, accuracy and reliability.

Geo-ICT will have a significant impact on Geomatics sector, industry, research and academia. This emerging Geo-ICT will open up many new applications resulting from a great improvement of data flow efficiency, dissemination, on-line data processing, quality management and calculable savings of operational costs of geo-information products.

\section{Adoption of Geo-ICT in Nepal}

In over 50 years of history of Survey Department, the technologies and corresponding policies have undergone tremendous change. Speedy development of technology in the field of surveying and mapping demands the changed role of surveyors and surveying institutions.

Survey Department is responsible for cadastral survey and preparing land records or establishing cadastre. Cadastral survey is the source of key information for the comprehensive Land Information System. An efficient Land Administration can not be imagined without accurate and reliable cadastral information.

Survey Department is gradually and slowly replacing the traditional methods adopting modern methods but yet much remain to be done. Survey Department, so far, is not in the stage of fully exploiting the Geo-ICT

In this context, it has already introduced some of the systems such as establishment of Geodetic Network and densification of control network by Global Positioning System Survey, Topographical base maps updating using Remote Sensing technology and Nepal-India border strip mapping by Geographical Information System technique and Digital technology for cadastral mapping. .

The advancement of Geo-ICT technology has been so rapid that it is supposed to be very difficult to adopt in our organization by virtue of lack of resources (Human, finance and others). Majority of the Human resources are turning out of date with the speed of change.

In Nepal, university education in Geomatics started only recently. Indeed low levels of technology, less skilled staff and exhausted processes are the critical issues in geospatial field. Appropriate ICT investment and capacity building are necessary conditions for establishing accurate geodata management for sustainable development. Education, training and research on geoinformation science are the fundamental factors for sustainable Geo-ICT use.

Although the cadastre system was focused to fiscal purpose in the beginning, it is being gradually used as legal and multipurpose cadastre. Updating of the cadastral maps is undertaken by district survey offices of Survey Department. Computerization of existing land records and cadastral maps to develop land information system and provide computer-based land administration services is under progress.

Land Administration is strongly influenced by social, cultural and bureaucratic environment, and overlooking of the existing practices and capacity would make failure in adopting such new technology. In this context, Geo-ICT has the vital role to play and has to be looked upon the overall objective

\section{Progress so far achieved in adopting Geo-ICT}

GPS survey for establishing geodetic controls was initiated by Survey Department in 1992. This survey is continuing to provide necessary control points to support cadastral surveying in different districts of the country.

Survey Department produced a new series of Topographic Base Maps between 1992 to 2001 at the scale of 1:25,000 (for the terai and middle mountains) and the scale of 1:50,000 (for the higher mountains and Himalayas) covering entire country in paper print. And subsequently converted all those maps into digital form by GIS technology and made available to the users as National Topographical Database (NTDB). Survey Department is working to create digital data files at smaller scales as well. Data files at a scale of 1: 100,000 are already available and has a plan to produce in 1:250,000, 1:500,000 and $1: 1000,000$.

With the mission of strengthening and developing geographic information infrastructure for the access of geographic and related data for decision-making, National Geographic Information Infrastructure Project (NGIIP) was established under Survey Department in 2002. This project facilitates the sharing of Geographical information among Geographical information user organizations within the country. This project has published Socio-economic atlas of Nepal and made available in CD-ROM, hard copy and on the web.

Topographical base maps, which were prepared during 1990's are updating with Remote Sensing 
Technology. Survey Department has also prepared Global map of Nepal, Ortho-photomaps of Urban areas, and has developed an Operational Metadata system through NGIIP. The department also provides CD of Soil and Terrain Data of Nepal SOTER NEPAL Version: 1

Survey Department proposed Cadastral Logical Framework Plan in Fiscal Year 2005/2006 with a vision of replacing traditional technology with digital technology in ten years time. In this line Cadastral Survey Branch under Survey Department started re-cadastral mapping by Digital technology and development of Land related information system from 2006 in Ward no. 6 of Banepa Municipality of Kavre District as a piloting project. After evaluating the success of piloting job, survey was extended to the rest of the wards too. Survey works have been finished so far in 9 out of 11 wards of the Municipality. Surveys in rest of the two wards are continuing. Survey Department has proposed a plan of extending this kind of job in Dhulikhel Municipality for the coming fiscal year.

Significant numbers of Geo-referenced cadastral map sheets from various district survey offices have been digitized and being digitized by Department of Land Information and Archive. Survey Department can use these data if needed.

Himalayan Airborne Gravity survey is on the way to achieve a modern Geoid model for Nepal to contribute to Geodetic Network Infrastructure of Nepal.

\section{Capacity building for efficient Geo-ICT application}

The present pace of progress in Cadastral surveying in Village blocks and Topographical map cyclic updating seems far lag behind to meet the real sense of cadastral mapping and topographical map updating. It would take many many years to complete at the current rate of progress; so that it should be accelerated with unconventional methods.

Peoples of the urban areas are demanding accurate and reliable measurements of their land, but the present method applied in cadastral surveying is the traditional graphic method using plane tables, and does not fulfill the requirements of the people. The methodology adopted does not contain the dimensions of the parcel, and the cadastral plan does not meet the needs of the people. Furthermore, digital cadastral mapping is needed to cover the interest of the people.

Survey Department is thinking of initiating cadastral survey through applications of high-resolution satellite data for the generation of ortho-images for Achham and Arghakhanchi districts, where old cadastral records were completely destroyed by arsenal during conflict.

Our present capacity may not be sufficiently supportive to bring about the desired result with the situation at hand. The accomplishment of above mentioned jobs can be materialized only if we strengthen our current capability. Immediate plan of action for Capacity Building is thus an essential aspect to be addressed upon before adopting Geo-ICT for our anticipated purpose.

Geo-ICT offers an opportunity to build land administration enhanced and efficient. But in a developing country like Nepal, where traditional methods or processes are still in practice, full fledged Geo-ICT application is still a far-cry. However, constant efforts for positive development should not be left out.

Effective utilization of any technology depends mainly on the qualified and well trained manpower. So, effective education and training programs are to be imparted. Attempts are on in this direction. Kathmandu University and Land Management Training Center have collaboratively commenced academic under-graduate course of B.E. in Geomatics Engineering since August 2007. Till date three batches have been enrolled. This program includes Geo-ICT based land administration education. Versatile and qualified manpower's team can be expected from academic course of B.E. in Geomatics Engineering.

Land Management Training Centre (LMTC) has a proposal to transform its one year Basic and Junior Surveyor's Courses into a three-year Diploma in Geomatics Engineering course, and to offer a two-year post-graduate degree programme.

The continuous support of ITC in providing scholarships to various level courses ranging from Diploma to Masters Level for capacity building of Survey Department has contributed. Coordination and cooperation among some other international organizations involved in space technology application and enhancing awareness in its importance could boost up the effectiveness. Furthermore, regional cooperation in this sector including human resource development, a proper platform for data sharing, etc. is equally essential for maximizing benefits.

The success of efficient Geo-ICT application heavily depends on the capacity building, institutional reforms, devolution or location based services, education and continuous training, and ultimately the commitment of the government. 


\section{Constraints}

In present context, Survey Department has following constraints for adopting an efficient adoption of Geo-ICT :-

- Lack of awareness among political leaders and policy planners resulting low priority in this discipline. There is little recognition that ICT can be used to supplement and complement the conventional system or processes,

- Lack of proper and sufficient education in this field, proper human resources and expertise.

- Lack of Infrastructure: Some of the problems include lack of reliable electricity supply, lack of bandwidth capacity in internet.

- $\quad$ Lack of financial support for managing Hardware, Software and Humanware.

- Related technology changes very fast and is difficult to keep pace with such changes.

- Replacement of traditional equipments and methodologies by digital technology has tremendously demanded increased and enhanced knowledge and skill.

- The original cadastral plans of half of the districts of Nepal were based on local survey control. They are described as so-called island maps and those map sheets are in hardcopy format. The "island maps" are not geo-referenced and hence cannot be digitized directly into the geo-spatial database.

\section{Issues to be addressed}

Adopting Geo-ICT remains a complex problem in Survey Department and the implementation of Geo-ICT is certainly a challenging task ahead in the present context. A firm commitment on the part of Policy planners, high level managers and whole hearted support from all the staffs to transform the technology may be the starting point.

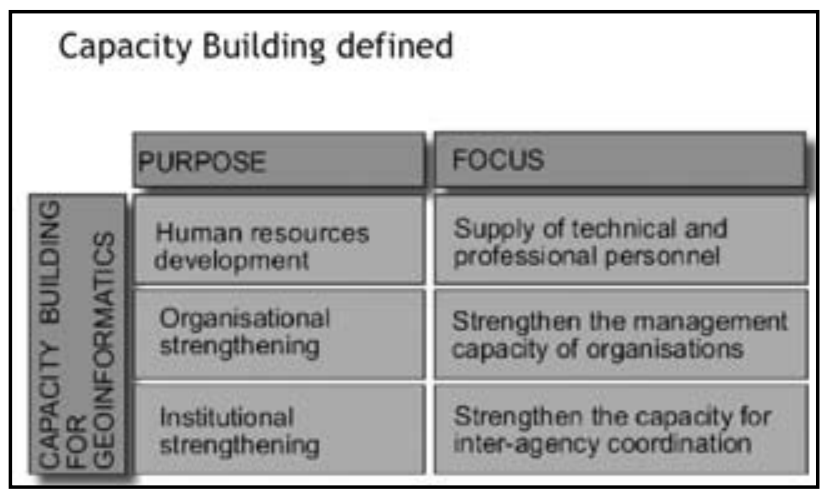

The following prime issues were identified for successful implementation of Geo-ICT:-

Technical issues, which include system components, system design, and technical expertise; Project management and process re-engineering related issues;

Organizational issues, which include how well the staff of an organization understands the technology and its role, and how the organization adapts to new sources and types of information;

Institutional issues, which include factors external to an agency that influence an organization's ability to adopt or use Geo-ICT.

\section{Plan of Actions}

The efforts should be concentrated for the following plan of actions to adopt Geo-ICT effectively and efficiently:-

1. All the issues namely technical, organizational, project management, and institutional are important for geoinformation management in the country. These issues are to be addressed while making plan of actions.

- Development of human resource is a pre-requisite; a continuous system of education, training and technology transfer need to be planned in house or abroad.

- Job placement and transfer should be wisely administered.

- Hardware and software:

- adding Geo-ICT aids,

- its maintenance and updating

- Policy for the Geo-ICT to be adopted to ensure effective and efficient utilization of resources.

- A strategy for formulating measures to control brain-drain.

- Organizational re-structuring suited to Geo-ICT need to be carefully planned.

- Resistance and/or non-cooperation from the existing staff in adopting new technology need to be addressed effectively 
- A strategy for the transformation from manual to Geo-ICT (re-engineering) has to be carefully planned and adopted

- Participation of the public and private parties: and winning their faith in the new system is a prerequisite: However, there are very few private parties, which can contribute to the implementation in Nepal.

2. Geo-ICT applications at present have disgraceful implementation scenario. Hence a strong need for research is felt in the area of geo-information management in the country.

3. Task force on 'Geo-information management' can be suggested by inducting professionals having expertise in technical, organizational, project management, and institutional areas. This task force should be assigned to bring out a business model for Geo-ICT products at Private partnership for its greater sharing between various stakeholders.

\section{Private participation in Geo-ICT}

All necessary conditions for the successful adoption of Geo-ICT cannot be imagined to be materialized only through the governmental efforts. In the new political environment, there may not be of exclusive control of government in mapping and geo-information sector.

Realizing the role of Private Parties in the changed context, Land (Survey and Measurement) Act, revised in 1999 made a provision of licensing to qualified surveyors, twenty seven surveyors have already got licenses, but have not fully implemented yet due to lack of supportive regulations and few other bureaucratic reasons. It can be expected that the system will start soon. Licensing surveyor's participation in Geo-ICT application in the country can be expected. Their activity will have some kind of direct or indirect influences in Survey Department as well.

There are four professional associations namely Nepal Surveyor Society, Nepal Surveyor's Association, Nepal Remote Sensing and Photogrammetric Society, and the Nepal Association of Chartered Surveyors to promote the Geoinformatics profession. However, their activities in the professional development and contribution to the Geo-ICT technological development in their respective fields lag far behind. Their activities are found limited to arranging a few number of seminars and publication of journals.
Some private educational institutes including School of Geomatics and Himalayan College of Geomatic Engineering are also contributing Geo-ICT manpower development.

Currently the private sector has limited potential capacity to contribute to cadastral surveying and mapping. Private survey professionals are demanding establishment of a Survey Council for the development and promotion of healthy, independent and responsible professionalism. Framing and enactment of a Survey Council Act is believed to strengthen, promote and protect private surveyor's role.

Survey Department should take a pivotal role in the country through Public-Private Partnership and Public-Public Partnership by bringing in the professional's associations and private licensed Surveyors in Geo-ICT activities for land management.

\section{Conclusions}

In spite of numerous constraints, the importance of Geo-ICT applications can not be neglected to keep pace with the advancement of technology and to serve the overall development of the country. Due to various reasons mentioned above the Department has not been in position to adopt Geo-ICT to desired potential. So, national and international cooperation in this respect might be the possible solution to address the capacity building of the department. However, Government policy makers continued support and the participation of the stakeholders are also equally vital for its sustainability.

The success of Geo-ICT heavily depends on the capacity building, institutional reforms, devolution of functions and services, education and continuous training, and ultimately the full commitment of the government and other stake holders.

\section{References:}

1. Babu Ram Acharya, 2009, Adopting Geo-ICT application for LandAdministration, $7^{\text {th }}$ FIG Regional Conference paper

2. Maheshwar Bhattarai, 2005, Land Resource Management and Human Resource in context of space technology application in Nepal, A seminar paper

3. Pramod K. Singh, 2008, Opportunities and challenges, GIS Development, 2008 August. 
4. Rabin Kaji Sharma and Toya Nath Baral, 2005, Survey Department in the General Context of Land Management, Proceedings of the colloquium on the role and functions of Survey Department in the context of broader technological development

5. R.R.Chhatkuli, 2002, National Geographic Information Infrastructure, Programme to support NGIS in Nepal, Nepalese Journal on Geoinformatics, Vol 1

6. Sjaak Beerens, 2006, Building Capacity in Geoinformation Handlings, Archives of Remote Sensing and Spatial Information Science, Vol. $X X X V I$ 